2010s-13

\title{
A Note on Remittances in El Salvador and Ecuador: An Analysis of Household Survey Data
}

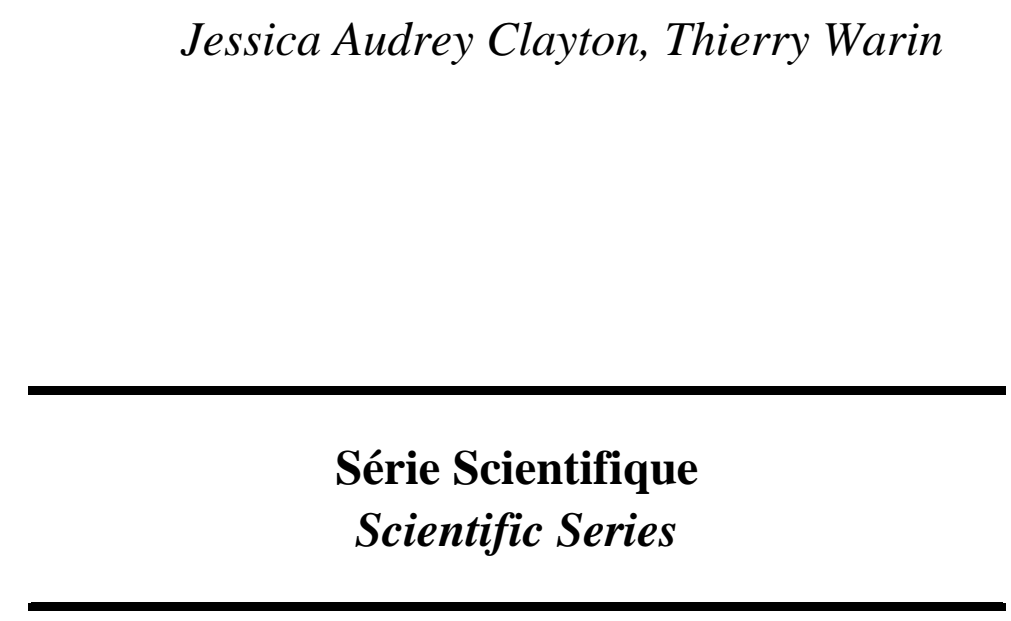

\author{
Montréal \\ Mars 2010
}

(C) 2010 Jessica Audrey Clayton, Thierry Warin. Tous droits réservés. All rights reserved. Reproduction partielle permise avec citation du document source, incluant la notice $\odot$.

Short sections may be quoted without explicit permission, if full credit, including @ notice, is given to the source.
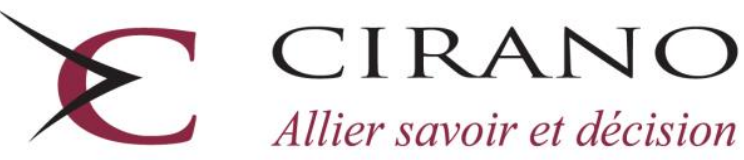

Allier savoir et décision

Centre interuniversitaire de recherche en analyse des organisations 


\section{CIRANO}

Le CIRANO est un organisme sans but lucratif constitué en vertu de la Loi des compagnies du Québec. Le financement de son infrastructure et de ses activités de recherche provient des cotisations de ses organisations-membres, d'une subvention d'infrastructure du Ministère du Développement économique et régional et de la Recherche, de même que des subventions et mandats obtenus par ses équipes de recherche.

CIRANO is a private non-profit organization incorporated under the Québec Companies Act. Its infrastructure and research activities are funded through fees paid by member organizations, an infrastructure grant from the Ministère du Développement économique et régional et de la Recherche, and grants and research mandates obtained by its research teams.

\section{Les partenaires du CIRANO}

Partenaire majeur

Ministère du Développement économique, de l'Innovation et de l'Exportation

\section{Partenaires corporatifs}

Banque de développement du Canada

Banque du Canada

Banque Laurentienne du Canada

Banque Nationale du Canada

Banque Royale du Canada

Banque Scotia

Bell Canada

BMO Groupe financier

Caisse de dépôt et placement du Québec

DMR

Fédération des caisses Desjardins du Québec

Gaz Métro

Hydro-Québec

Industrie Canada

Investissements PSP

Ministère des Finances du Québec

Power Corporation du Canada

Raymond Chabot Grant Thornton

Rio Tinto

State Street Global Advisors

Transat A.T.

Ville de Montréal

\section{Partenaires universitaires}

École Polytechnique de Montréal

HEC Montréal

McGill University

Université Concordia

Université de Montréal

Université de Sherbrooke

Université du Québec

Université du Québec à Montréal

Université Laval

Le CIRANO collabore avec de nombreux centres et chaires de recherche universitaires dont on peut consulter la liste sur son site web.

Les cahiers de la série scientifique (CS) visent à rendre accessibles des résultats de recherche effectuée au CIRANO afin de susciter échanges et commentaires. Ces cahiers sont écrits dans le style des publications scientifiques. Les idées et les opinions émises sont sous l'unique responsabilité des auteurs et ne représentent pas nécessairement les positions du CIRANO ou de ses partenaires.

This paper presents research carried out at CIRANO and aims at encouraging discussion and comment. The observations and viewpoints expressed are the sole responsibility of the authors. They do not necessarily represent positions of CIRANO or its partners. 


\title{
A Note on Remittances in El Salvador and Ecuador: An Analysis of Household Survey Data*
}

\author{
Jessica Audrey Clayton ${ }^{\dagger}$, Thierry Warin
}

\begin{abstract}
Résumé / Abstract
Ce papier a pour objectif de proposer une étude de cas sur l'impact des transferts de fonds individuels des émigrés vers leur village d'origine. L'étude repose sur des données collectées dans le cadre d'entretiens individuels réalisés dans trois villages: Cumbe et Gualaceo (Equateur) et Ciudad Romero (El Salvador). Les résultats contredisent, dans le cadre de ces villages, certaines études précédentes qui concluaient en l'absence d'impacts de long-terme des fonds transférés. En utilisant un modèle simple fondé sur la méthode des moindres carrés ordinaires complété par une analyse de variance multi-variée, cette étude montre un impact positif des transferts de fonds sur l'investissement, en plus d'être un soutien financier pour les produits de première nécessité.
\end{abstract}

Mots clés : transferts de fonds, Amérique latine, développement économique, capital humain, aide internationale

This study analyzes the impact of remittances as seen in household survey data from three small rural communities. OLS and multivariate anova regressions were used to analyze household survey data collected in Cumbe and Gualaceo (Ecuador) and in Ciudad Romero (El Salvador). The results contradict the findings of some studies concluding that in many countries remittances acted as "compensation for poor economic performance" rather than capital promoting economic development.

Keywords: remittances, Latin America, development, human capital, foreign aid

Codes JEL : F22, F24, I32, R23, R51

\footnotetext{
* The assistance of Sophie Morse in collecting surveys in Ciudad Romero, El Salvador and the cooperation of The Foundation for Self-Sufficiency in Central America were extremely appreciated. The authors would also like to thank Sarah Emmons and Leah Shakleton. Finally, the authors would like to credit the study to all of the survey respondents in Cumbe, Gualaceo and Ciudad Romero. The usual caveats apply.

$\dagger$ Middlebury College, USA

† Middlebury College, USA \& Cirano, Canada, twarin@ middlebury.edu
} 


\section{INTRODUCTION AND LITERATURE REVIEW}

The paper addresses the question of the impacts of remittances in three villages in El Salvador and Ecuador. Remittances, most often defined as monetary transfers from a migrant to a relative or friend back home, now represent a fairly substantial portion of the Gross Domestic Product (GDP) of several developing countries. From 2002 to 2007, the inflow of remittances to developing countries more than doubled, from $\$ 116$ billion in 2002 to $\$ 265$ billion in 2007, the inflow of remittances to developing countries more than doubled.

Neyapti (2004) observed that for developing countries, the stability of remittances improved as inflow quantities increased. In 2007, Roache and Gradzka found that even when the business cycle of the US fluctuated, remittance levels were maintained. Similarly, the International Monetary Fund (IMF) noticed that indeed, in times of market hard-ships, remittance flows remain fairly steady in comparison to other economic inflows, often lessening the blow of a market shock: "Remittances have proved remarkably resilient in times of economic downturn" (2005). Because remittances flow directly into the hands of the people in each country, the impact of decreasing flows has the potential to cause a devastating loss of familial and personal incomes for recipients of all classes. For the families surveyed for this study, the stability of remittances may determine the likelihood of a child's school enrollment, a father affording his heart medication, or affording a better roof before the arrival of the next rainy season.

The literature thus far remains fairly divided as to the success of remittances in aiding development in both market sectors and in the lives of receiving families. On the one hand, Aghion and Bolton (1997) summarize the potential of accumulating capital, describing remittance inflows as "more and more funds available in the economy to finance a smaller and smaller pool of borrowers." This increase in financial backing could ultimately lead to economic development for entire economies. Many authors support this idea (Zarate-Hoyos 2004; Aggarwal, Demirguc-Kunt, and Peria 2006; Acosta, Fajnzylber and Lopez 2007). On the other hand, some studies argue that remittances do not aid capital market development, nor do they encourage investment and development of family finances. Instead, remittances simply help to maintain a subsistence income for receiving families (Ang 2007; Skeldon 2008; Chami, Fullenkamp and Jahjah 2005). Adams (2005a) and Cordova (2004) argue that, in fact, the increased consumption of receiving families, citing housing, education and health care as examples, should be considered an increase in investment. These expenditures demonstrate a continued impact of received funds through increases in human, as well as physical capital. Remittances affect the economic health of a country, as well as the personal livelihood and financial capability of the country's remittance-receiving families. 
FIGURE 1. REMITTANCE RECEIPTS (\% OF GDP) IN ECUADOR AND EL SALVADOR, 1990-2005

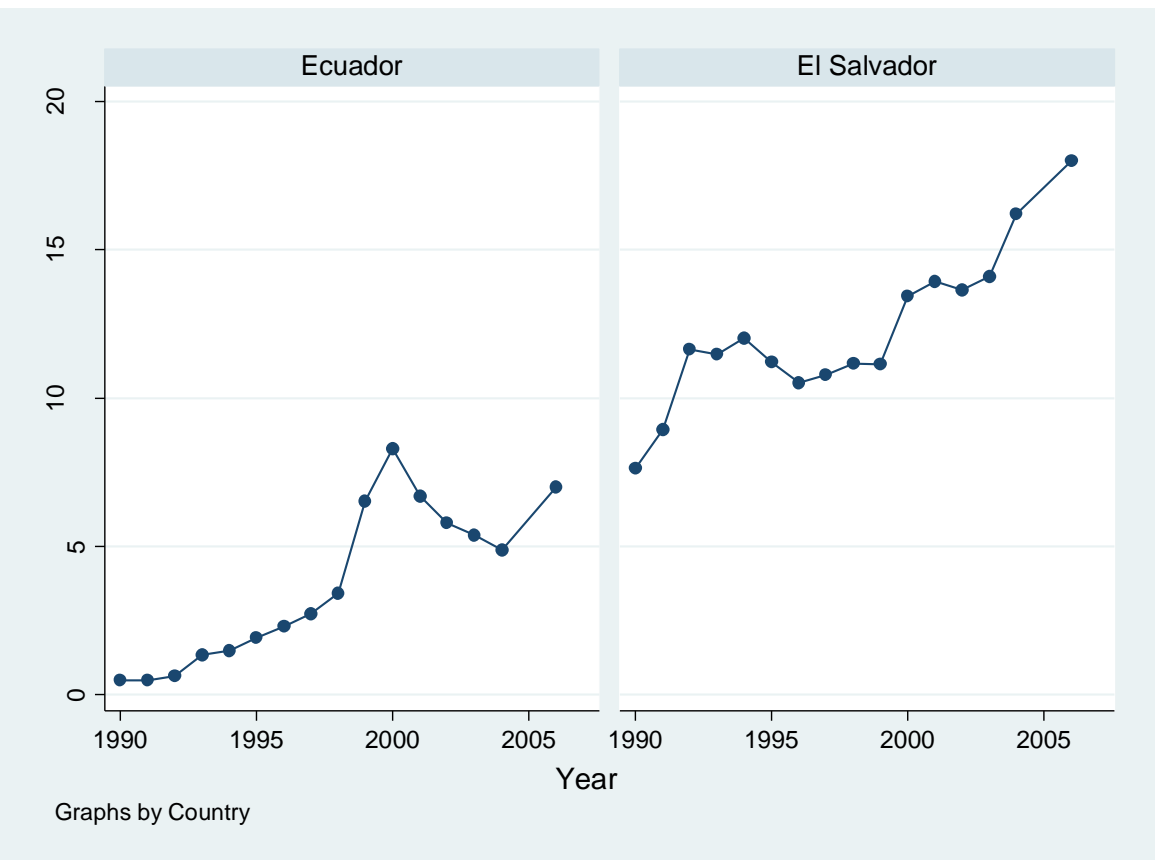

Source: DataGob Database, IADB

In 2005, the United Nations acknowledged the potential positive correlation between remittance flows and financial development in receiving countries with a conference devoted to the importance of encouraging the utilization of remittances in development projects within their Millenium Goals (UNDP 2005). In country and area-specific studies, as well as global overviews, authors have demonstrated the correlation between remittances and local, as well as global, economic development (Gupta, Pattillo and Wagh 2007; Pieke, Van Hear and Lindley 2007; Adams 2005b; Lopez-Cordova and Olmedo 2007). The development impacts of remittances are derived from a variety of remittance-driven sources. Due to increased incomes, remittance-receiving families have the newfound ability to access financial institutions and an increased desire to use them. A steady flow of remittances can provide poor families with the financial history required to partner with formal institutions, thereby expanding the "access frontier," as well as increasing business for institutions (Toxopeus and Lansink 2007). Studies of Africa found that large financial flows increased the demand for financial access, thereby encouraging the development of the financial industry (Gupta, Pattillo and Wagh 2007; Pieke, Van Hear and Lindley 2007). In Sri Lanka, the resulting increase in financial infrastructure brought on by remittances was said to represent movement towards economic development (Lasagabaster, Maimbo, and Hulugalle 2005).

Thus, while remittances may assist the consumption of individual households, studies argue about the limited nature of the flows. If funds are not put into institutions that can reach the public, such as savings accounts or investment firms, will the development benefits aid the economy country-wide? Macro-data compiled by the World Bank for Ecuador and El Salvador shows fairly steady rates of domestic savings and household consumption, despite increasing remittance quantities. Interestingly, El Salvador seems to have a recent trend in decreasing savings rates along with increasing remittance rates. 
FIGURE 2. GROSS DOMESTIC SAVINGS, HOUSEHOLD CONSUMPTION EXPENDITURE AND REMITTANCE RECEIPTS AS A PERCENT OF GDP OVER TIME, 1990-2007

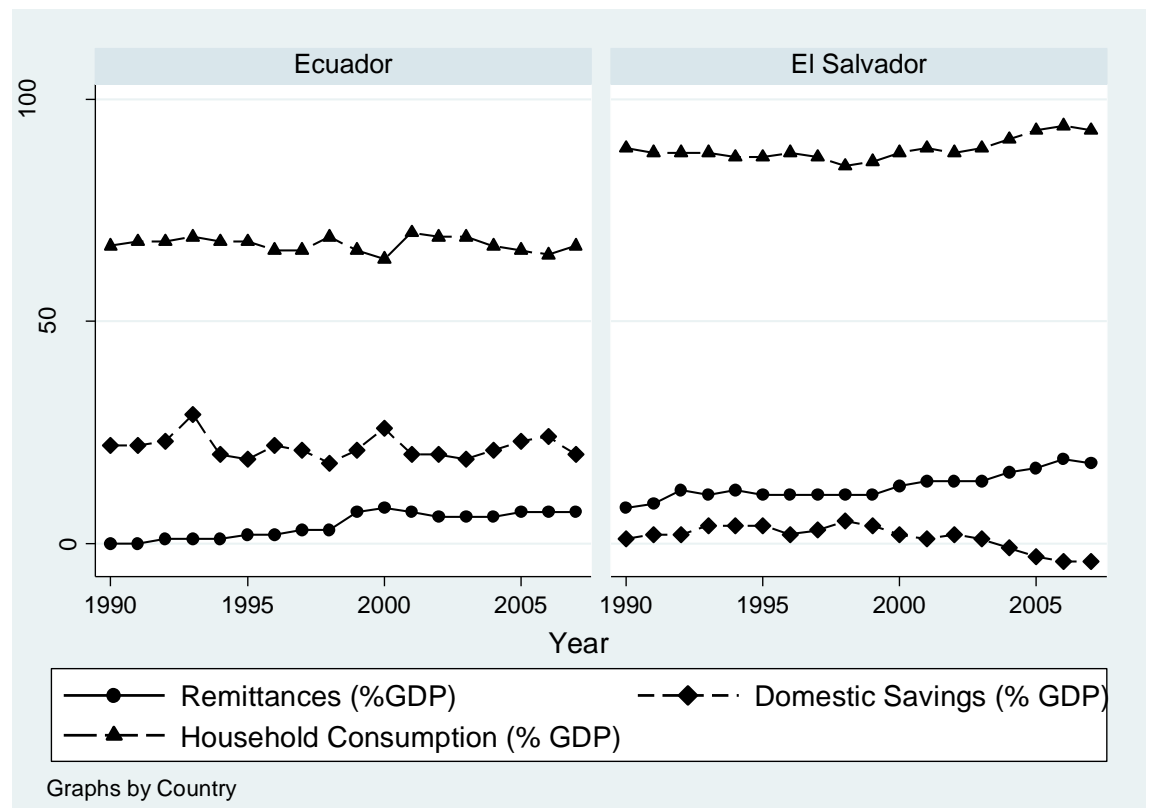

Source: World Bank Development Indicators Online.

As direct financial inflows, remittances represent additional available resources for receiving households. Several studies have demonstrated that remittances create, on average, a 31 percent increase in household income (Nguyen 2008; Caceres and Saca 2006; Acosta Fajnzylber and Lopez 2007; Calero, Bedi and Sparrow 2008). In a macroeconomic sense, remittances represent increased capital for receiving countries. On the base level, they impact the lifestyle and purchasing power of families, which can spread to macroeconomic change. In cases where remittances reach beyond the levels necessary to achieve subsistence consumption, they can reduce liquidity constraints for low-income families and allow for increased expenditure (Nguyen 2008; Caceres and Saca 2006; Giuliano and Ruiz-Arranz 2005; Borraz 2005). Studies in Latin America found that remittances tend to increase expenditures, especially increased subsistence consumption (Caceres and Saca 2006; Acosta, Fajnzylber and Lopez 2007; Calero, Bedi and Sparrow 2008). In Vietnam, remittance recipients increased expenditures by 12 percent on average (Nguyen 2008).

On a broad scale, increased financial flows to a country represent the opportunity for development through investment. A quantitative analysis of remittance-receiving Mexican communities found that the presence of remittances in a family's income increased the likelihood of a family member to start a business by 16 percent (Massey and Parrado 1998). Remittances, however, have shown a tendency to promote investment through non-traditional and non-formal means by choice of recipient families. Household data from Guatemala revealed that with increased remittances, households spent a lesser percentage at the margin on consumption, while spending an increased percentage on housing and 
education, which should be considered investment goods (Adams 2005). Paralleling the findings in Guatemala, Zarate-Hoyos (2004) found that while consumption quantities increased in Mexico for remittance-receiving households, it remained the same as a percentage of income, with additional money invested in vehicles and housing.

\section{DATA AND METHODOLOGY}

The data were gathered through household surveys conducted in June of 2008 and February of 2009. The survey was completed by at least 30 households in each town, and there were a total of 96 surveys collected. Due to high rates of illiteracy in the areas surveyed, surveys were conducted in interview fashion. A lack of sure knowledge and complete information as well as a tendency to base answers on broad estimations by respondents resulted in average-based numerical answers for income, remittance receipts, and time-based answers. In Ecuador, the surveys were conducted in the rural market towns of Gualaceo and Cumbe. In El Salvador, surveys were conducted in the Bajo Lempa region, in the town of Ciudad Romero.

The survey contains questions designed to elicit household and demographic characteristics, including the standings of the previous generations in terms of education and work. The current characteristics obtained by the survey includes a sample of each household's composition through questions on the age, education, and occupation of all household members, as well as financial income and the property status of each home. The survey elicited basic data of the migrant, including the relationship to the remittance receiving family member, their occupation abroad, time abroad, marital status, and the location of any spouse or children reported.

Finally, the survey gathered information on the inflow of remittances-the amount, frequency, any changes in flows, the impact of the migrant's legality, a perception of reasons for the migrant sending funds, main uses by receiving families, and their own perceived need for the funds each month. In several cases, the sensitivity of questions regarding the legality of migrants abroad resulted in few answers. When survey recipients neglected to answer whether or not their relative was legal, illegality abroad was assumed.

The survey revealed that among sample populations, the three towns demonstrated an average income of around 50 dollars a month per household, although 24 percent of households could not report a monetary income. The towns are largely based in subsistence living, and agriculture, mostly corn farming, was reported as the largest industry. Families consisted of an average of 4 to 6 people living in each household, with 1 to 3 working members, and 1 to 3 children under the age of 18 . The average emigration rate was an impressive 63 percent, and of the families with migrants, 62.5 percent reported more than one family member working abroad. The most common response when asked why they sent a migrant abroad was in search of work for needed pay, because, as they said, "aquí no hay nada de hacer. Aquí no hay nada." (Here there is nothing to do. Here there is nothing.) 
TABLE 1. SUMMARY OF SURVEY STATISTICS

\begin{tabular}{|r|r|}
\hline \multicolumn{1}{|c|}{ Characteristic } & Percent of Sample \\
\hline Family Size & $27 \%$ \\
1 to 3 & $48 \%$ \\
4 to 6 & $20 \%$ \\
7 to 10 & $5 \%$ \\
$10+$ & \\
\hline 0 & $3 \%$ \\
1 to 3 & $84 \%$ \\
4 to 6 & $8 \%$ \\
7 to 10 & $5 \%$ \\
\hline Number of Workers & \\
\hline 0 & $8 \%$ \\
1 to 3 & $66 \%$ \\
4 to 6 & $21 \%$ \\
7 to 10 & $4 \%$ \\
$10+$ & $1 \%$ \\
\hline Number of Children & $66 \%$ \\
\hline Owns house & $62.50 \%$ \\
\hline Has a Migrant & $62 \%$ \\
\hline Multiple Migrants & $96.50 \%$ \\
\hline Illegal & $84 \%$ \\
\hline Has a Family & \\
\hline
\end{tabular}

TABLE 2. FINANCIAL STATISTIC SUMMARY

\begin{tabular}{|r|c|c|}
\hline (\$/month) & Income Level & Remittance Receipts \\
\hline Unkown/Varies & $24 \%$ & $10 \%$ \\
0 to 50 & $32 \%$ & $15 \%$ \\
50 to 100 & $18 \%$ & $28 \%$ \\
100 to 150 & $7 \%$ & $10 \%$ \\
150 to 200 & $2 \%$ & $13 \%$ \\
200 to 250 & $5 \%$ & $3 \%$ \\
250 to 400 & $6 \%$ & $15 \%$ \\
400 to 800 & $4 \%$ & $5 \%$ \\
\hline
\end{tabular}

Of families with a migrant abroad, 75 percent reported receiving a remittance, and amounts received were fairly well spread out by quantity amidst a modal value of 50 to 100 dollars per month. It is important to note that the surveys of Ecuador were done in the summer of 2008, and those in El Salvador in February of 2009, after the financial downturn in the United States. Several respondents in El Salvador answered questions based on the usual remittance receipts of past months, because at the time of the survey, they were experiencing a hiatus in inflows. As they explained, "Ya no hay trabajo allá tampoco" (Now there is no work over there either). The community in El Salvador treated the change as temporary, likely due to fear.

\section{RESULTS}

In order to examine the categorical variables, a multivariate anova regression and an OLS model were used. 
TABLE 3. RESULTS: LIKELIHOOD OF A MIGRANT IN THE FAMILY

\begin{tabular}{|c|c|c|}
\hline \multicolumn{2}{|r|}{ OLS } & Std. err. \\
\hline \multicolumn{3}{|l|}{ Migrant in Family } \\
\hline Number of Workers & $-.2449133^{\star *}$ & 0.0886746 \\
\hline Constant & $.9125848^{* * *}$ & 0.1125338 \\
\hline R-squared & 0.0758065 & \\
\hline N. of cases & 95 & \\
\hline \multicolumn{3}{|c|}{${ }^{*} \mathrm{p}<0.05,{ }^{* *} \mathrm{p}<0.01,{ }^{\star * *} \mathrm{p}<0.001$} \\
\hline \multicolumn{3}{|c|}{ Anova } \\
\hline & Coef. & Std. err. \\
\hline \multicolumn{3}{|l|}{ Migrant in Family } \\
\hline \multicolumn{3}{|l|}{ Number of Workers } \\
\hline 1 to 3 & $.8^{*}$ & 0.3457903 \\
\hline 4 to 6 & $.4625^{\star}$ & 0.2182694 \\
\hline 7 to 10 & 0.2285714 & 0.277249 \\
\hline Contant & 0.2 & 0.2117524 \\
\hline$\overline{\overline{\text { R-squared }}}$ & 0.0770621 & \\
\hline N. of cases & 95 & \\
\hline \multicolumn{3}{|c|}{${ }^{*} \mathrm{p}<0.05,{ }^{* *} \mathrm{p}<0.01,{ }^{* * *} \mathrm{p}<0.001$} \\
\hline
\end{tabular}

Following the assumed necessity of a migrant abroad for a family to receive a remittance, the first relationship analyzed was that of the number of workers in a family with the likelihood of having a migrant in the family. The OLS regression revealed a significant negative relationship. The anova, however, revealed a more complex story. The model found a positive significant relationship significant for families with one to three workers, with a coefficient of 0.35 , and for families with four to six workers, with a coefficient of 0.22 . The relationship was statistically insignificant for families with seven to ten workers. These correlations most likely reflect the capability of a family with a greater number of workers to have a higher base income. Therefore, larger families do not exhibit the need to augment their income with a migrant. The coefficient is most robust for the smallest number of workers, and although it remains significant, decreases for the middle range before decreasing for families where the majority of household members are employed.

In an attempt to explore the remittance decisions of migrants, as well as the debated issue of the impact of time on remittances, the study analyzed the relationship of a migrant's having a nuclear family in the origin country and the migrant's relationship to the surveyed head of household with the time the migrant had been abroad at the time of the survey. Again, in both models, the only statistically significant relationship to the surveyed head of household was that of spouse, with significance and strength of the coefficient decreasing from the OLS to the anova model. 
TABLE 4. RESULTS: TIME A MIGRANT SPENDS ABROAD

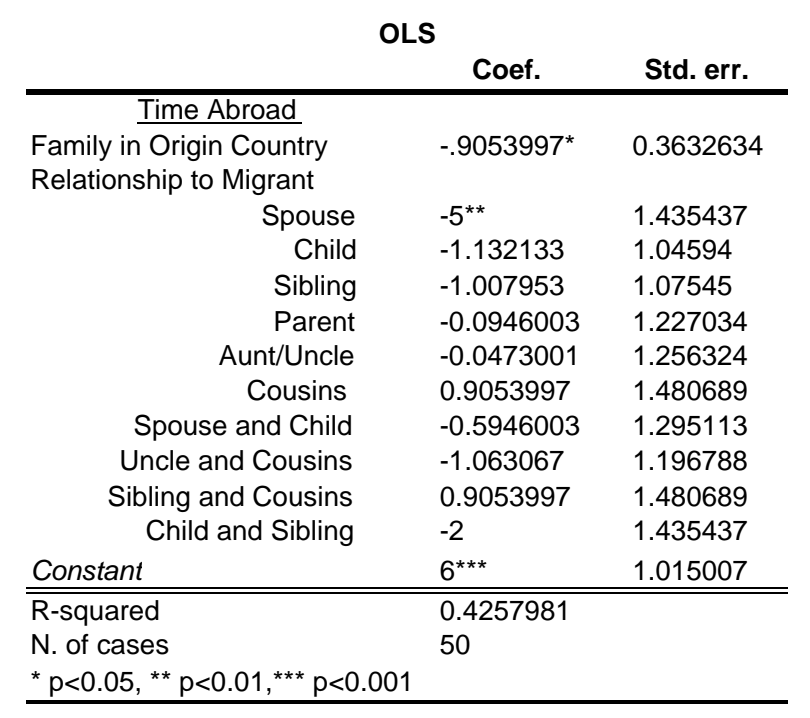

\begin{tabular}{|c|c|c|}
\hline \multicolumn{3}{|c|}{ Anova } \\
\hline & Coef. & Std. err. \\
\hline \multicolumn{3}{|l|}{ Time Abroad } \\
\hline Family in Origin Country & $-.9053997^{\star}$ & 0.3632634 \\
\hline \multicolumn{3}{|l|}{ Relationship to Migrant } \\
\hline Spouse & $-3^{*}$ & 1.435437 \\
\hline Child & 0.8678666 & 1.04594 \\
\hline Sibling & 0.9920469 & 1.07545 \\
\hline Parent & 1.9054 & 1.227034 \\
\hline Aunt/Uncle & 1.9527 & 1.256324 \\
\hline Cousins & 2.9054 & 1.480689 \\
\hline Spouse and Child & 1.4054 & 1.295113 \\
\hline Uncle and Cousins & 0.9369332 & 1.196788 \\
\hline Sibling and Cousins & 2 & 1.435437 \\
\hline Child and Sibling & 2.9054 & 1.480689 \\
\hline Constant & $4^{* \star *}$ & 1.015007 \\
\hline$\overline{\overline{\text { R-squared }}}$ & 0.4257981 & \\
\hline N. of cases & 50 & \\
\hline${ }^{*} \mathrm{p}<0.05,{ }^{* *} \mathrm{p}<0.01,{ }^{* * *} \mathrm{p}<0.001$ & & \\
\hline
\end{tabular}

The anova regression revealed two significant positive relationships for migrants demonstrating the highest number of years abroad. Those who had been abroad from two to five years showed a coefficient of 0.304 , and those gone from six to ten years held a more robust coefficient of 0.359 . Here it may be important to note that those surveyed were illiterate and in rural communities. Both factors likely correlate with a limited international skill set of the migrant upon emigration, classifying the migrants from the communities surveyed as part of the second, more unskilled group. 
TABLE 5. RESULTS: LIKELIHOOD THAT A FAMILY RECEIVES A REMITTANCE

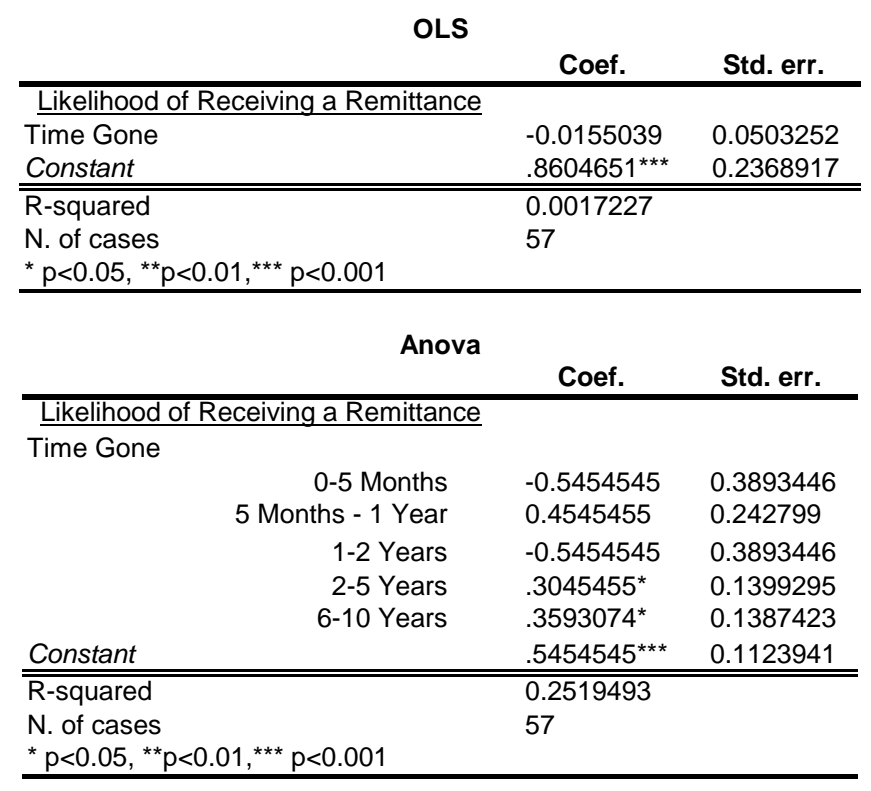

Further exploring the remittance decisions of the migrant abroad, remittances may vary based on the perceived needs of the family left at home by the migrant. To examine this theory from the receiving end, the study explored the relationship between families who owned their own home and family income levels with the remittance quantity they receive per month. The OLS analysis revealed a negative correlation between owning a home and receiving a remittance, while the anova revealed a slightly less significant positive correlation with an almost identical coefficient. The results of the OLS regression parallel the findings of Meckel (2008), demonstrating that the poorest families are more likely to feel the need to send a migrant abroad, and thus to receive remittances. However, the anova regression indicates evidence that the cost of migration may indeed limit the poorest families from sending a migrant abroad. It also exhibits the positive impact of remittances on the ability to purchase a home. The later results correlate with the findings of Adams and Page (2005), whereby migration and remittances have a Ushaped relationship.

TABLE 6. RESULTS: REMITTANCE QUANTITY RECEIVED (DOLLARS PER MONTH)

\begin{tabular}{lcc}
\multicolumn{1}{c}{ OLS } & \\
& Coef. & Std. err. \\
\hline Remittance Received (\$/month) & & \\
\cline { 2 - 3 } Owns House & $-2.626702^{\star *}$ & 0.9453749 \\
Income & $.5131752^{\star *}$ & 0.1611677 \\
Constant & $4.793808^{\star * *}$ & 0.9818159 \\
\hline \hline R-squared & 0.3821493 \\
N. of cases & 33 \\
${ }^{*} p<0.05,{ }^{* *} p<0.01,{ }^{* * *} p<0.001$ & & \\
\hline
\end{tabular}




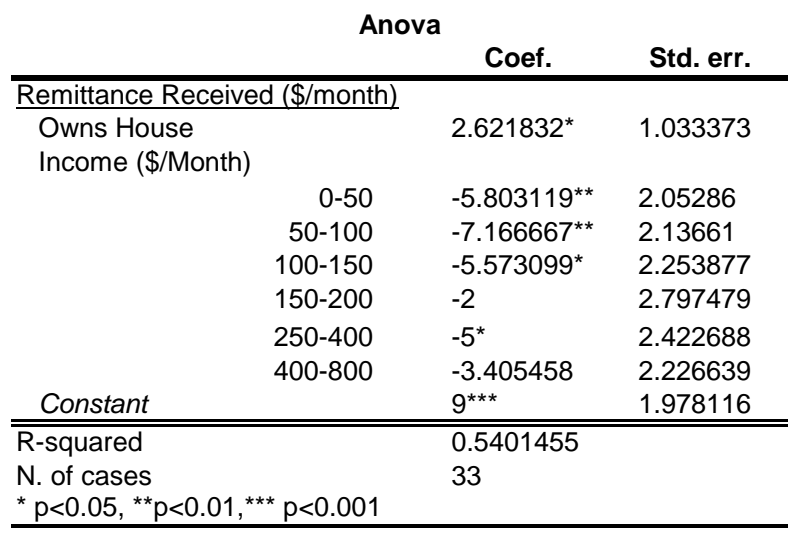

Continuing the replication of Adams and Page's (2005) U-shaped findings, income held a significant positive relationship to remittances with a coefficient of 0.513 in the OLS regression. The anova model, however, found significant negative relationships at income levels of \$0-50, \$50-100, and \$100-150 a month, with robust coefficients averaging at around -5.5. Interestingly, the relationship was also significant, although less significant, at the income level of $\$ 250-400$. This may be a result of the limited number of observations seen at that income level.

TABLE 7. RESULTS: LIKELIHOOD OF A FAMILY OWNING THEIR OWN HOME

OLS

Coef. Std. err.

\begin{tabular}{lrr}
\hline \multicolumn{1}{c}{ Owns House } & & \\
Income Level & 0.034848 & 0.031471 \\
Remittance Received & $-.0779169^{\star}$ & 0.028043 \\
Constant & $1.038724^{* *}$ & 0.123904 \\
\hline \hline R-squared & 0.205806 \\
N. of cases & 33 \\
* $p<0.05,{ }^{* *} p<0.01,{ }^{* * *} p<0.001$ \\
\hline
\end{tabular}




\begin{tabular}{|c|c|c|c|}
\hline \multicolumn{4}{|c|}{ Anova } \\
\hline \multicolumn{4}{|c|}{ Owns House } \\
\hline \multicolumn{4}{|c|}{ Income (\$/Month) } \\
\hline & $0-50$ & $-1.082524^{\star *}$ & 0.3688547 \\
\hline & $50-100$ & $-.9974452^{*}$ & 0.3786937 \\
\hline & $100-150$ & $-1.12233^{* *}$ & 0.3295368 \\
\hline & $150-200$ & -0.7553397 & 0.5303205 \\
\hline & $250-400$ & $-1.071065^{\star}$ & 0.4190531 \\
\hline & $400-800$ & $-.7553397^{\star}$ & 0.357913 \\
\hline \multicolumn{4}{|c|}{ Remittance Received (\$/Month) } \\
\hline & $0-50$ & $1.039074^{\star \star}$ & 0.2676936 \\
\hline & $50-100$ & $1.061898^{\star * *}$ & 0.2422039 \\
\hline & $100-150$ & $.7208311^{*}$ & 0.2862792 \\
\hline & $150-200$ & $.5106795^{\star}$ & 0.2302013 \\
\hline & $200-250$ & $.7553397^{\star}$ & 0.357913 \\
\hline & $250-400$ & $1.080232^{\star * \star}$ & 0.2745847 \\
\hline & $400-800$ & $.7553397^{\star}$ & 0.357913 \\
\hline Constant & & $1^{\star *}$ & 0.2767111 \\
\hline$\overline{R \text {-squared }}$ & & 0.7036494 & \\
\hline N. of cases & & 33 & \\
\hline${ }^{*} \mathrm{p}<0.05,{ }^{* *}$ & $n=0001$ & & \\
\hline
\end{tabular}

Finally, to investigate the small-scale influence of remittances on living standards, and potentially also on economic development, the relationship between income and remittance receipts to the likelihood of a family owning their home was analyzed. The OLS regression revealed a small negative coefficient between remittances and the likelihood of owning a home, significant at the .05 level. The anova revealed significant positive relationships to remittance receipts at every level, with the most significant levels being \$50-100 and \$250-400 a month, and the largest coefficient of 1.08 also for remittances at the \$250400 a month level. Remittance receipts often reduce the liquidity restraints of receiving families, making purchasing or constructing a home more feasible.

\section{CONCLUSION AND POLICY IMPLICATIONS}

The survey analysis results add a glimpse into the reality of remittances: from the impact of increased school enrollment to the improved ability for a family to buy their child the school uniform required to attend classes. To fully understand remittances, one should keep in mind the lives behind the seemingly miraculous funds. Policies should be directed at meeting the needs and desires of remittance recipients.

Results from survey data analysis exhibit a tendency for remittances to flow to members of the middle or lower classes. The analysis of the impact of income on remittances revealed a robust negative relationship for the bottom three income levels as well as the second to top income tier in the communities. However, the analysis did reveal that a decrease in the number of workers in a family increased the family's likelihood to have sent a migrant abroad; the fewer the number of workers in a family, especially in rural cities, the smaller the possible household and per capita income. Since having a migrant is inevitably associated with an increased likelihood of receiving a remittance, migrant-sending families are assumed to be increasing their chances of augmenting an income already below that of other families. By increasing their incomes, families with a migrant can experience upward social mobility and approach financially those in the community with larger initial base incomes. This may not completely equalize incomes between socioeconomic classes, but the disparity will be reduced and overall growth potential capability will increase. 


\section{REFERENCES}

Acosta, Pablo, Pablo Fajnzylber and J. Humberto Lopez (2007). “The Impact of

Remittances on Poverty and Human Capital: Evidence from Latin American Household Surveys." World Bank Policy Research Working Paper \#4247.

, Pablo, Cesar Calderon, Pablo Fajnzylber and Humberto Lopez (2007). "What is

the Impact of International Remittances on Poverty and Inequality in Latin America?" World Bank Policy Research Working Paper \#4249.

Adams, Richard H. Jr. and John Page (2003). "International Migration, Remittances and

Poverty in Developing Countries." The World Bank: Poverty Reduction Group Working Paper \#3179. (December).

, Richard H. Jr. (2005). "Remittances, Household Expenditure and Investment in

Guatemala." Development Research Group; The World Bank Policy Research Working Paper \#3532.

Aggarwal, Reena, Asli Demirguc-Kunt, and Maria Soledad Martinez Peria (2006). “Do

Workers' Remittances Promote Financial Development?" The World Bank Policy Research Working Paper \#3957. Pp. 1-39.

Aghion, Philippe and Patrick Bolton (1997). “A Theory of Trickle-Down Growth and

Development." The Review of Economic Studies, Vol. 64, Issue 2. (April). Pp. 151-172.

Ang, Alvin P. Phd (2008). "Workers' Remittances and Economic Growth in the

Philippines.” Social Research Center: University of Santo Tomas.

Borraz, Fernando (2005). “Assessing the Impact of Remittances on Schooling: the

Mexican Experience.” Global Economy Journal. Vol. 5, Issue 1, No. 9.

Caceres, Luis Rene and Nolvia N. Saca (2006). "What do Remittances Do? Analyzing the Private Remittance Transmission Mechanism in El Salvador." International Monetary Fund Working Paper \#6250.

Calero, Carla, Arjun S. Bedi and Robert Sparrow (2008). "Remittances, Liquidity

Constraints and Human Capital Investments in Ecuador.” IZA Discussion Paper \# 3358.

Chami, Ralph, Connel Fullenkamp, and Samir Jahjah (October 2003). “Are Immigrant

Remittance Flows a Source of Capital for Development?” IMF Working Paper \#3189.

Cordova, Jose Ernesto Lopez (2004). “Globalization, Migration and Development: The 
Role of Mexican Migrant Remittances." Inter-American Development Bank Working Paper Series.

Giuliano, Paola and Marta Ruiz-Arranz (2005). “Remittances, Financial Development, and Growth.” IMF Working Paper: Research Department. (December).

Gupta, Sanjeev, Catherine Pattillo and Smita Wagh (2007). "Impact of Remittances on

Poverty and Financial Development in Sub-Saharan Africa." International Monetary Fund Working Paper \# 0738.

International Monetary Fund. (2005). World Economic Outlook: Globalization and External Imbalances (April).

Lasagabaster, Esperanza, Samuel Munzele Maimbo, and Sriyani Hulugalle (2005). "Sri

Lanka's Migrant Labor Remittances: Enhancing the Quality and Outreach of the Rural Remittance Infrastructure." World Bank Policy Research Working Paper 3789. (December).

Lopez-Crodova, J. Ernesto and Alexandra Olmedo (2007). "International Migration,

Remittances and Development: An Overview." Integration \& Trade. No. 27. (July-December).

Massey, Douglas and Emilio Parrado (1998). "International Migration and Business

Formation in Mexico.” Social Science Quarterly. Vol. 79, No. 1. (March).

Meckel, Katherine (2008). "Remittance Behavior among New U.S. Immigrants.” Federal

Reserve Bank of Chicago: Working Paper \#19. (December).

Neyapti, Bilin (March-April 2004). “Trends in Workers' Remittances: A Worldwide

Overview." Emerging Markets Finance and Trade, Vol. 40, No. 2. (March-April). Pp. 83-90.

Nguyen Viet, Cuong, (2008). "Do Foreign Remittances Matter to Poverty and Inequality?

Evidence from Vietnam.” Economics Bulletin, Vol. 15, No. 1. Pp. 1-11.

Pieke, Frank N., Nicholas Van Hear, and Anna Lindley (2007). "Beyond Control? The

Mechanics and Dynamics of 'Informal' Remittances Between Europe and

Africa." Global Networks. Vol. 7, No. 3. Pp. 348-366.

Roache, Shaun K. and Ewa Gradzka (2007). "Do Remittances to Latin America Depend

on the U.S. Business Cycle?” International Monetary Fund Working Paper \#273.

Skeldon, Ronald (2008). “International Migration as a Tool in Development Policy: A

Passing Phase?" Population and Development Review, Vol. 34, No. 1. Pp. 1-18.

Toxopeus, Helen S. and Robert Lensink. (2007). "Remittances and Financial Inclusion in

Development.” United Nations University: Research Paper \#49. 
UNDP (2005). "The Potential Role of Remittances in Achieving the Millenium

Development Goals - An Exploration.” UNDP Capacity Development Group and Bureau for Development Policy, in Partnership with the Rockefeller Foundation. (October 10).

Zarate-Hoyos, German A. (2004). "Consumption and Remittances in Migrant

Households: Toward a Productive Use of Remittances." Contemporary Economic Policy, Vol. 22, No. 4. Pp. 555-565. 